\title{
Saving Europe's dolphins
}

\author{
Mark P. Simmonds
}

\begin{abstract}
Current evidence suggests that Europe's dolphins in the 1990s require urgent action to conserve them. This paper reviews the nature of the threats to these animals and outlines some measures designed to help counter them.
\end{abstract}

World-wide, there are about 80 species that may be referred to as whales, including dolphins and porpoises (May, 1990). All belong to the order Cetacea, which is divided into the Mysticeti (or baleen whales) and the Odontoceti (or toothed whales). 'Dolphin' and 'porpoise' are popular names for many of the smaller toothed species. The term 'great whale' is usually used for the baleen (filterfeeding) species and the sperm whale - a toothed but large (and, at one time, commercially important) species. 'Small cetaceans' generally refers to all the others. In international law, confusion in the terminology affects the protection afforded different species.

The International Convention for the Regulation of Whaling was signed in Washington in December 1946. This established the International Whaling Commission (IWC), which has traditionally limited its attention to the larger whales (Lyster, 1985). Indeed, the text of the Convention refers only to 'whales' and this ambiguity, coupled with the IWC's traditional focus, means that there is no global agreement or expert body concerned with the smaller species.

In Europe a wide range of cetaceans with differing habitat requirements occur in a small geographical area. Twenty-five species have been recorded in historical times in the waters of the North Sea and Channel around the UK (Evans, 1990a). Of these, 11 are recorded regularly (Table 1), with the bottlenose dolphin and harbour porpoise the most commonly encountered species, probably because they are the only two that regularly use inshore waters. Evans (1990a) suggests that the white-beaked dolphin is the most abundant dolphin species in the North Sea, while the common dolphin is the most abundant in the Channel.

Harbour porpoises are normally seen swimming in small groups in the murky waters of bays and estuaries (Martin, 1990), whereas bottlenose dolphins are often seen leaping high out of the water. Both coastal and offshore populations of bottlenose dolphins exist and the species occupies diverse habitats ranging from open coasts with strong surf to large estuaries (Martin, 1990). The nearshore type is generally reported to occur in discrete units with limited home ranges and the offshore form is believed to make seasonal migrations following prey movements (Klinowska, 1991).

Little is known about the habitats of whitebeaked and common dolphins. The populations of the former are scattered widely over the continental shelves, with some evidence of concentration on the shelf edges and slopes. The common dolphin is encountered mainly in deep offshore water where zones of upwelling may be of particular importance for them (Martin, 1990).

Dolphins have a relatively low reproductive rate. The age of sexual maturity ranges from 3 years for common dolphins, to 11-12 years for bottlenose dolphins and up to 16 years for killer whales (Evans, 1987; Klinowska, 1991). Gestation periods are 10-16 months and lactation, for some species, probably continues for 18-20 months. Most female cetaceans probably calve only every 2-3 years.

Dolphins are usually social animals, living in well-co-ordinated groups and the mothercalf bond is obviously strong for most species. Bottlenose dolphins demonstrate a range of differing social strategies. The occasional friendly solitary individuals have become famous world-wide (see Lockyer, 1990 for a 
full review), but this species is more commonly encountered in small groups, and schools of several hundred are sometimes reported offshore in other parts of the world (Martin, 1990).

These highly mobile animals can cover great distances, often searching collaboratively to find fish and cephalopods, food resources that are typically patchy and unpredictable. High mobility and sometimes seasonal migrations are, thus, vital to these predators, especially as they appear unable to fast for long periods of time (May, 1990; Reijnders, 1992).

The relatively low reproductive rate of the dolphins and their wide ranging behaviour, combined with their position as top predators in the marine food chain, make them particularly vulnerable to certain threats from humans in Europe, and elsewhere.

\section{Threats to cetaceans}

Five human-related categories of threat can be identified (Evans, 1990a):

1 hunting;

2 depletion of food resources by over-fishing;

3 incidental entanglement in fishing gear;

4 pollution;

5 disturbance.

\section{Hunting}

World-wide, the annual 'directed take' of dolphins, porpoises and small whales exceeds 100,000 (Evans, 1987). In Europe the only remaining major hunt is in the Faroe Islands. This 'drive fishery' takes an average of 848 pilot whales annually (Zachariassen, 1993) and some 15,000 were killed between 1970 and 1984 (Julshamn et al., 1987). Although the focus is on pilot whales, an expedition to the islands in 1991 by the British Divers Marine Life Rescue discovered the mutilated remains of a large number of dolphins in one of the bays where pilot whales are herded and killed (R. Gravener, pers. comm.). Elsewhere, in European and contiguous waters, small numbers of dolphins are still taken opportunistically and there are occasional reports of
Table 1. Cetacean species regularly recorded in the North Sea and Channel (Evans, 1990a)

\section{Odontocetes}

Harbour porpoise Phocoena phocoena*

Bottlenose dolphin Tursiops truncatus*

Common dolphin Delphinus delphis

White-beaked dolphin Lagenorhynchus albirostris

Atlantic white-side dolphin Lagenorhynchus acutus

Risso's dolphin Grampus griseus

Long-finned pilot whale Globicephala melas

Orca (or killer whale) Orcinus orca

Sperm whale Physeter macrocephalus

\section{Mysticetes}

Fin whale Balaenoptera physalus

Minke whale Balaenoptera acutorostrata

*The only species regarded as having inshore habitats

dolphin on the menus of restaurants (notably on Mediterranean coasts) (R. Aguilar, pers. comm.). Some killing also undoubtedly results from the perceived conflict between humans and dolphin for fish, and 'bow-riding' dolphins make easy targets.

\section{Food depletion}

Consideration of possible prey depletion needs to take into account prey availability and behaviour, as well as the cetaceans' hunting methods. Common, white-beaked dolphins, bottlenose dolphins and harbour porpoises all eat a variety of fish and cephalopods (Evans, 1987). Observations of well-organized and collaborative activity include reports of dolphin schools moving in tight formation over a wide area, possibly in acoustic or visual contact with each other, using echolocation clicks to find fish (Würsig, 1986; Evans, 1990a). Once prey is located, the dolphins may herd the fish to concentrate them or trap them against a shoreline or the water surface. Such collaborative activities undoubtedly help to harvest effectively patchy prey in circumstances where the hunters have a 'tight energy' budget (Reijnders, 1992), which effectively limits the time they can go without food.

Harbour porpoises generally make seasonal migrations, which follow the movements of 
fish stocks (Reijnders, 1992), and their coastal distribution around the UK closely coincides with the distribution of herring spawning grounds (Evans, 1990b). During the period when the North Sea directed herring fishery was closed (1977-81) after a severe decline in catches, porpoise numbers along North Sea coasts also fell (Reijnders, 1992). The herring stock in fact collapsed to an estimated 5 per cent of its post-war level and mackerel stock followed the same pattern. Other fish, which the porpoises might then have substituted in their diet, could have proved to be less suitable for their metabolism (Reijnders, 1992). Whiting, for example, contain fewer calories per unit body weight than herring or mackerel. The conclusion, therefore, seems to be that there was simply not enough prey to support the porpoise population. The implications of this for other small cetaceans are unclear.

\section{Incidental entanglement in fishing gear}

The accidental capture of small cetaceans in fisheries is common in Europe (Reijnders, 1992). The IWC has drawn special attention to the incidental take of striped dolphins in the Mediterranean, concluding that the population is unable to endure the current level of removal (Klinowska, 1991). Drift-nets are a particular concern. At the time of writing, the use of drift-nets longer than $2.5 \mathrm{~km}$ by European fishing fleets is a highly controversial issue (Anon, 1994). The UK, France and Spain, for example, are in dispute over the use of these nets in the Bay of Biscay. An investigation by Greenpeace of the nets of the French Albacore Drift-net fleet (some 37 vessels) operating in the north-east Atlantic suggested that in one season alone the fleet might catch some 1300 common dolphins and 900 striped dolphins as well as many other non-target animals (Woodley and Earle, 1991). The results of a further study of the French albacore tuna drift-net fishery indicated an incidental cetacean take of some 1700 animals a year (Goujon et al., 1993). Other fishing techniques vary in their impacts on dolphins, although set nets of various types may also be dangerous (Klinowska, 1991). Clausen and Andersen
(1988) estimated that up to 3000 harbour porpoises died annually in Danish set nets in the Skagerrak and North Sea and perhaps several thousand more in other fisheries. More recently, Vinther (1994) estimated the bycatch for all Danish gill-nets in the North Sea at 7000 harbour porpoises annually. Such accidental 'bycatch' is a sensitive issue for fishermen, who may be reticent to report entangled dolphins. As a result, data on the scale of incidental take in Europe are scarce.

The 1988 Annual Meeting of the IWC Scientific Committee established a Workshop on the Mortality of Cetaceans in Passive Fishing Nets and Traps and this was held in La Jolla, California, in October 1990. The participants concluded that 'wherever cetaceans and gill-nets are found in the same area, at least some cetaceans are caught' (IWC, 1990). They also reported that 'small cetaceans have sensory abilities which potentially can detect the webbing and rigging of gill-nets and other passive fishing gear. Encounters with nets may occur as they forage or engage in other activities which increase the chances that they will fail to detect nets.' They recommended that rigorous investigations into how entanglement occurs must be made 'as a matter of urgency' and concluded that the lack of understanding about this phenomenon meant that 'at this time there is no practical universal modification of fishing gear which can be suggested to solve all problems of incidental entrapment of cetaceans. In urgent cases ... there may be no alternative but to ban the fishery.'

Some further indication of the scale of incidental take in Europe may be provided when conditions conspire to bring a proportion of the bycatch mortality ashore. Strandings of very large numbers of dead dolphins have recently occurred on the French Atlantic and Cornish coasts. In the first few months of 1988 , 1989, 1990 and 1991, several hundred dolphins (mainly common dolphins) in a variety of states of decomposition were washed ashore on the Atlantic coast of France (Charreire, 1992; Simmonds and Hutchinson, 1994). Judging from evidence of entanglement on some of the bodies examined part of this mor- 
tality at least was the product of fisheries operations in the preceding weeks in the Bay of Biscay (Charreire, 1992).

More recent data are not available for the French coasts, but a significant and unusual stranding of common dolphins occurred on the Cornish coast in early 1992. Some 120 carcasses came ashore, a number with evidence of having been caught in nets. Pathological investigations confirmed that they were bycaught animals (Kuiken et al., 1994). The investigators suggested that a trawl or purse seine fishery was probably involved and noted the potential significance of 'pair-trawling', where two powerful boats tow between them a large net at great speed.

The numbers of dead dolphins involved in the French and Cornish events only provide a 'snapshot' of bycatch in one part of Europe's seas. An unusually large number of common dolphins was present inshore off Cornwall at about the same time as the mass stranding; one school was estimated at over 1000 animals (Simmonds and Hutchinson, 1994). The interception of large schools by one or more fisheries, with resultant large mortalities, is probably quite common on the high seas.

Cetacean populations, because of their relatively low reproduction rate, are not thought capable of withstanding sustained incidental mortality. One model developed for harbour porpoises suggests that even a loss of 4 per cent per year would be too great (Woodley and Read, 1991). The 1990 workshop on cetaceans and fisheries suggested that kill rates as low as 2 per cent per year may not be sustainable, depending on the life history of the species and the age and sex composition of the kill (IWC, 1990).

\section{Pollution}

While quantifying the mortality arising from fisheries bycatch is difficult, the threat is relatively easy to comprehend. This is not the case when considering pollution. Cetaceans in European waters have been shown to accumulate high concentrations of organochlorines and heavy metals in their tissues. These contaminants have been associated with a variety of abnormalities in other vertebrate species (Safe, 1984; Peterle, 1991). Organochlorines, in particular, may induce reproductive and immune system dysfunction, as evidenced in seals (Hutchinson and Simmonds, 1994; de Swart et al., 1994). Reproductive failure in a number of populations has been linked to organochlorines (Simmonds, 1992) and it has been shown experimentally that PCBs and DDT in the diet of Wadden Sea harbour seals Phoca vitulina are responsible for their poor reproductive performance in recent years (Reijnders, 1986).

Table 2. Marine mammal mass mortalities since 1987 and factors that have been so far associated with them (expanded from Simmonds, 1992)

\begin{tabular}{|c|c|c|c|c|c|c|c|c|}
\hline \multicolumn{3}{|l|}{ Mortality } & \multicolumn{6}{|l|}{ Factor } \\
\hline Date & Location & Species & Approx. size & A & B & $\mathrm{C}$ & $\tilde{D}$ & $\mathrm{E}$ \\
\hline $1987 / 88$ & Siberia & Baikal seals & $8,000 ?$ & $+?$ & - & - & + & - \\
\hline $1987 / 88$ & US (East Coast) & Bottlenose dolphins & 2,500 & - & - & + & + & + \\
\hline 1988 & Northern Europe & Harbour seals & 18,000 & + & + & $+?$ & + & + \\
\hline $1990 / 91$ & US (Gulf of Mexico) & Bottlenose dolphins & 300 & - & - & - & + & - \\
\hline $1990-92$ & Mediterranean & Striped dolphins & 7,000 & + & - & - & + & + \\
\hline 1993 & US (Gulf of Mexico) & Bottlenose dolphins & ? & - & - & - & + & - \\
\hline
\end{tabular}

+ , evidence of an association between the mortality and factor.

- , no evidence to date.

A, mortality preceded by 3 months when air temperature higher than the 10 -year average.

$B$, population believed to be at high density.

C, algal bloom.

$\mathrm{D}$, morbillivirus infection.

$\mathrm{E}$, pollution. 
Bioaccumulated pollutants in harbour seals also came under close scrutiny during the 1988 European seal epizootic. Mortality varied regionally and organochlorine burdens were greatest in the populations where the highest mortalities occurred (Simmonds et al., 1993). Other research showed that organochlorine concentrations were higher in the blubber of animals that died than in the survivors (Hall et al., 1992). It is thus probable that such pollutants exacerbated the effects of a virusinitiated mortality. Their presence in the body of seals challenged by the virus could have made the animals initially more susceptible to infection. Moreover, sick seals were clearly unable to dive (the symptoms were generally like those of pneumonia) and animals that did not die swiftly would have mobilized food reserves in their blubber. In doing so they would also have released quantities of organochlorines previously sequestered. Diseased animals are affected by many stresses in addition to those imposed directly by a primary infective agent (Eis, 1989). In the case of the 1988 seal epizootic this was a morbillivirus new to science. The additional stress imposed by pollutants could have made the difference between recovery and death.

In recent years, marine mammal populations world-wide have been affected by a spate of similar mortalities (Table 2). These have been linked to a variety of potential stressors, including global climatic change, but, invariably, they have occurred in waters adjacent to highly industrialized coastlines (Simmonds, 1992). The severity of the recent die-off of thousands of striped dolphins in the Mediterranean has also been strongly associated with bioaccumulated pollutants (Aguilar and Raga, 1990). Recent research into the epizootic has determined that the dead animals were contaminated with PCB concentrations higher than in the population at large (Kannan et al., 1993). The researchers concluded that 'efforts to avoid further contamination by PCBs in the Mediterranean are necessary to avoid outbreaks of marine mammal epizootics.'

Polyaromatic hydrocarbons (PAHs) have been detected in harbour porpoises from UK waters (Law and Whinnett, 1992). Some PAHs can be metabolized to carcinogenic diolepoxide and it may be significant that the death of one harbour porpoise (out of a sample of 27 for which cause of death could be determined) was recently attributed to cancer (Law et al., 1992). There is also an example of a UK dolphin calf where death might have been caused by liver damage resulting from the transfer of pesticides and PCBs in its mother's milk (Morris et al., 1989). An estimated 80 per cent of the maternal organochlorine body burden mobilized from the blubber during lactation may pass to the first-born dolphin calf (Cockcroft et al., 1989).

Physiological effects in cetaceans that have been directly linked to contaminants are, however, rare. A study of adrenocortical hyperplasia in a small sample of harbour porpoises (a condition linked to organochlorine exposure in other species) failed to find a correlation with organochlorines (Kuiken et al., 1993). However, a correlation with suppressed male sex hormone (testosterone) levels has been indicated by a study of oceanic Dall's porpoises in the Pacific (Subramanian et al., 1987). Even offshore species may be heavily contaminated, as shown for pilot whales in the north-east Atlantic (Simmonds et al., 1994).

While most attention may have focused on the potential affects of organic compounds, heavy metals should not be ignored. A study in the US linked liver disease with mercury accumulation in bottlenose dolphins (Rawson et al., 1993). Only livers that contained mercury concentrations of less than $50 \mathrm{ppm}$ (wet weight) were unaffected and levels in excess of this are far from uncommon in European cetaceans (see, for example, Law et al., 1992).

The scale of the threat of pollution to marine mammals has been hotly debated for some years but the emerging interest in the significance of ubiquitous lipophilic contaminants for humankind may now throw it into sharper focus. Some authorities suggest that pollution is actually the most serious threat to cetaceans, even claiming that it alone could lead to eventual extinction (for example, Cummins, 1988; Scheele in May, 1990). 


\section{Disturbance}

Disturbance, particularly noise, is the most difficult threat category to identify and investigate. Noise was first officially recognized as a 'pollutant' at the 1971 United Nations Conference on the Human Environment. Because marine mammals rely so heavily on sound to interpret their environment, it has been suggested that they may be especially vulnerable to noise disturbance (Reeves, 1992). Observations have been made of the responses of a range of cetacean species to various disturbances. Sounds generated by large vessels are usually at frequencies of 10-100 $\mathrm{Hz}$, rarely above $1 \mathrm{kHz}$, and overlap with the hearing ranges of mysticete whales. Evans (1990a), however, suggests that the main threat comes from fast pleasure craft, which generate sound in the $1-50 \mathrm{kHz}$ range, overlapping with the hearing range of dolphins and porpoises (1-150 kHz) and the main frequencies at which they vocalize.

Of particular significance may be the disturbance associated with oil exploration and development. Only two well-established, resident populations of bottlenose dolphins are known in the UK - in the Moray Firth in Scotland and in Cardigan Bay. Both areas are scheduled for oil exploration. The noise disturbance associated with the oil industry at sea includes seismic testing, drilling and production sounds, as well as that associated with aircraft and vessels visiting installations. There has been little research so far into the effects of large-scale industrial activities on cetaceans. However, bowhead whales were found to react to airguns used in seismic testing from as far away as $10 \mathrm{~km}$, at received noise levels of $160 \mathrm{~dB}$ or more (Ljungblad $e t$ al., 1985) and they consistently avoided fullscale seismic surveys by a distance of at least 2 $\mathrm{km}$ (Richardson et al., 1986).

What is of most concern is not the brief spells of aberrant behaviour resulting from disturbance but the potential exclusion of cetaceans from important habitat areas. The distribution of bowhead whales in relation to industrial activities in the Beaufort Sea was monitored for several years and the numbers using the main area of industrial activity - the MacKenzie Delta - where island construction, drilling, dredging and intensive boat and helicopter activity were in progress, diminished a few years after the onset of offshore drilling (Richardson et al., 1985, 1987). At the very least, disturbance could have important energetic considerations for animals with limited energy reserves and, at worst, whole populations might be excluded from important feeding, breeding or migrating grounds.

\section{The status of Europe's dolphins}

The deteriorating situation of the bottlenose dolphin and harbour porpoise in Europe is becoming clearer, although population declines of bottlenose dolphins cannot be quantitatively substantiated (Klinowska, 1991). Bottle-nose dolphins, which were reported in estuaries such as the Firth of Forth, Humber and Thames prior to 1900, are now rare at all these sites (Evans, 1990a). During the 1920s and 1930 s they were also common along the Channel coast of England, but are no longer.

The harbour porpoise is also in decline in a number of areas, closely linked to prey availability. Sightings data indicate that this species is now only rarely found in the inner and eastern Baltic Sea, the Wadden Sea, the southern North Sea and the Irish Sea (Reijnders, 1992). It is still common in the winter along the northern Dutch, German and Danish North Sea coasts and, in summer, east of England (Reijnders, 1992; Camphuysen and Leopold, 1993). In. Dutch coastal waters the species appears to have made a 'slight comeback, at least in winter, after a serious decline in the period 1940-80' (Camphuysen and Leopold, 1993). The whole year round it can be found in the northern North Sea and to the west of Scotland and Ireland. However, recent declines have also been noted in northern Scotland (Evans, 1990a). The harbour porpoise population in the North Sea as a whole has been calculated to have been reduced in recent years by $53,000-89,000$ individuals (Reijnders, 1992).

A sample of harbour porpoises caught inci- 
dentally by fishermen in Danish waters revealed that large (and therefore probably older) animals are now rare and that females were shorter (and probably younger) when they first became pregnant than animals previously examined (Clausen and Andersen, 1988). These effects are very similar to the changes observed in a population of striped dolphins on the Pacific coast of Japan, which was also subject to heavy losses, although in this case as a result of hunting rather than bycatch (Klinowska, 1991).

Anecdotal evidence about changes in the numbers of small cetaceans observed from the European coast is commonplace. Tregenza (1992) has quantified the observations of 1000 lay people in Cornwall and found a profound reduction of sightings during the last 50 years. The decline predominantly affected larger groups. Sightings of smaller groups showed no change and sightings of single dolphins increased. Harbour porpoises seemed to be the most common species observed in the early years of the survey and the author concluded that it is likely there had been a substantial fall in their numbers. Data are too few to comment on the past or present status of any of the offshore species.

Once cetacean populations have been depleted or entirely removed from an area, recolonization from surrounding populations may not occur. Reijnders (1992) suggested that this is one of the ongoing problems for harbour porpoises in the North Sea because there is now a lack of porpoises which 'traditionally' use some areas.

In conclusion, the available evidence indicates that small cetaceans in Europe have declined through a combination of incidental entanglement in fishing gear and prey depletion. Pollution and disturbance are also likely to be affecting them and in parts of the Baltic some populations are already extinct.

\section{Legislation for the conservation of small cetaceans}

There is currently no global agreement designed to aid small cetaceans. However, the
IWC could take small cetaceans under its auspices and they have been increasingly discussed by the Convention's Scientific Committee and working groups (Rose and Crane, 1993). The IWC has called for research into the situation of the harbour porpoise in Europe (Klinowska, 1991) and, in 1993, a resolution was passed concerning the need for a reduction of bycatches of harbour porpoises in the North Atlantic and Baltic (Lockyer and Müller-Helmbrecht, 1993). However, whether the IWC could effectively act to help conserve small cetaceans is debatable, especially because it has reached its own 'crossroads' (Rose and Crane, 1993). Pressure to resume commercial whaling is building. Norway conducted a commercial hunt in 1993 and Iceland has stated that it plans to follow suit. These and other pro-whaling states (Greenland and the Faroe Islands) have also formed a new organization, the North Atlantic Marine Mammal Conservation Organization (NAMMCO). These moves challenge the authority and effectiveness of the IWC.

In view of these developments, regional agreements might prove to be more effective. The European Community has recognized the problems of harbour porpoises and bottlenose dolphins by including them in Annex 2 of the 'Habitats Directive' (Council Directive 92/43/EEC of 21 May 1992 on the conservation of natural habitats and of wild fauna and flora). This means that Special Areas of Conservation (SACs) must be established and integrated into a 'coherent European ecological network'. All cetaceans are included in Annex 4 as 'species of Community Interest in Need of Strict Protection' and this prohibits deliberate capture, killing and disturbance (while allowing some derogations). However, the directive must be interpreted via national law and the network of SACs is being developed over a long time-scale. Parties have to propose sites to the Commission within 3 years of the notification of the Directive and sites of Community importance will be drawn from member states' lists and established within 6 years.

The recently ratified (29 March 1994) Agreement on the Conservation of Small 
Cetaceans of the Baltic and North Seas (ASCOBANS) was concluded in September 1991 and has as its primary objective 'to achieve and maintain favourable conservation status for small cetaceans'. What it does not have is an action plan identifying practical steps to fulfil this objective. Such a plan is urgently required for the agreement to be effective and should incorporate the following points.

'Favourable conservation status' in the context of ASCOBANS needs to be defined. In fact, the 'Habitats Directive' does this by defining criteria for 'favourable' conservation status:

(a) population dynamics data indicate that small cetaceans in the Agreement area are maintaining themselves on a long-term basis as a viable component of their ecosystems;

(b) the range of small cetaceans in the Agreement area is neither currently being reduced, nor is likely to be reduced, on a longterm basis;

(c) there is, and will be in the foreseeable future, sufficient habitat in the Agreement area to maintain small cetaceans on a long-term basis;

(d) the distribution and abundance of small cetaceans in the Agreement area approach historical coverage and levels.

'Conservation status' can therefore be taken as 'unfavourable' if any of the conditions (a-d) are not met and this provides a working basis for the implementation of any ASCOBANSrelated action plan. (This is also consistent with the wording of the Draft Agreement on the Conservation of Small Cetaceans of the Mediterranean and Black Seas and Contiguous Water, November 1992.)

Moreover, in order to ensure that conservation status moves towards (or is maintained at) a 'favourable' condition, a precautionary approach should be adopted where threats and status are unclear or ill-defined. In other words, suitable action will be taken where there is reason to believe that an adverse impact exists. The necessity of applying such a precautionary approach in environmental and conservation work is now recognized in a considerable body of international legislation, including, for example, the Declarations of the
North Seas Ministers Conferences.

An initial practical step would be the creation of SACs for small cetaceans, as required by the EC Habitats Directive, which states that they 'shall correspond to the places within the natural range of such species which represent the physical or biological factors essential to their life and reproduction.' These could be interpreted to mean feeding, breeding and calving grounds and perhaps areas through which small cetaceans regularly move or migrate. Effort needs to be put into identifying these areas and establishing suitable management regimes. For bottlenose dolphins, Cardigan Bay and the Moray Firth require such status.

Each protected area needs to be clearly delimited and, where appropriate, marked by suitable warning indicators. Kelleher and Kenchington (1992) in producing guidelines for marine protected areas for IUCN-The World Conservation Union, noted that, in the past the establishment of parks and reserves has failed to consider how the surrounding region may affect the park. They therefore recommended 'zoning'. For small cetaceans a two-zone model might be appropriate: an outer 'buffer zone' and an inner 'zone of full protection'. Wardens should also be appointed to ensure protection of small cetaceans and their habitats via implementation of suitable management regulations. A possible management regime is suggested in Table 3.

The issuing of licences (or permits) for human activities within each zones would need careful consideration. No licence or permit should be issued for either zone if the activity would compromise the conservation status of small cetaceans. Where there is any uncertainty the activity should be prohibited.

Outside the SACs, countries should implement the relevant international agreements that relate to pollution, for example, those outlined in the decisions of the North Sea Conferences.

The problems created by fisheries interactions are perhaps more difficult to resolve. Overfishing is clearly not in the best interests of humans or dolphins. The sustainable management of fish stocks is a target towards which various agencies are working. An extra 
dimension, which needs to be incorporated into any management strategy, is the scale of bycatch caused by different fisheries and techniques. Once such information is collected (via a dedicated fisheries observer programme perhaps based on that in operation in the USA), a licensing system could be established to control methods that create a high bycatch, limiting/restricting any impact on cetacean habitats and populations. The development of fisheries methods and equipment that avoid bycatch could also make a contribution.

Some fishermen may feel that such measures would be yet one more level of restraint on their activities, which in Europe are

Table 3. A proposal for a management regime for protected areas for cetaceans

\section{A. In the inner zone of full protection}

- All fisheries activity will be strictly controlled gill-nets will be prohibited and dredging, trawling and other fishery activity will be permitted only by licences subject to annual review.

- Other commercial and military traffic will be prohibited. Organized whale/dolphin watching will be limited to one boat for each protected area and will require a licence subject to annual review.

- Pleasure vessels will be prohibited from harassing small cetaceans (i.e. not approaching closer than $500 \mathrm{~m}$ - except where the animals choose to approach them - nor should vessels 'drive' the animals in any way).

- All research activities and research vessels operating in the zone must be licensed.

- No new discharges (industrial or domestic) will be made directly into the zone or into waters draining into it.

- All existing discharges must comply fully with relevant national and international legislation.

- The extraction of, or exploration for, minerals or other large-scale industrial activities will be prohibited.

\section{B. In the buffer zone}

- Gill nets will be prohibited. The situation with respect to other large-scale fisheries operations will be subject to review as further evidence about bycatch becomes available.

- No new discharges to sea will be made.

- Activities relating to mineral extraction and exploration will be subject to an annually reviewed licence. already affected by quotas and other limitations. However, such a response would preempt the findings of the proposed observer programme and its eventual marriage to measures designed to ensure sustainable exploitation of the fish stocks themselves. The techniques that may be found to be most problematical for dolphins could also prove to be those that pose the greatest threats to the future of the fish stocks (for example, drift-nets).

Kelleher and Kenchington (1992) emphasized that consideration should be given to compensation for local inhabitants where rights and practices are lost. They refer specifically to the effects resulting from the creation of marine protected areas. The first such sanctuaries for small cetaceans will probably be coastal and conflict of interests with fisheries is likely to be limited (inshore crab and lobster 'potters' are unlikely to constitute a threat to dolphin species), but nevertheless, this needs to be carefully and fully addressed.

With respect to deliberate killing, this must be unequivocally outlawed, as required by ASCOBANS (which also notes the obligation to release immediately any animals caught alive and in good health').

Finally, it is important that the public, and in particular the fishermen, support initiatives for small cetaceans. Educational and publicity material explaining the need for the conservation of small cetaceans needs to be produced and widely distributed within the member nations of the EU.

These suggestions are presented in order to promote the development of action plans consisting of practical conservation measures for small cetaceans in Europe, particularly under the auspices of ASCOBANS. Without such activities, the future of European dolphins looks bleak.

\section{Acknowledgments}

This paper was born out of conversations with many concerned individuals too numerous to name but I am particularly grateful to Nicky, Paul, Judy, Anna and Alison for their help and to the anonymous referees who commented on the first draft. 


\section{References}

Aguilar, A. and Raga, J.A. 1990. La mortandad de delfines en el Mediterraneo. Política Cientifica, 25, 51-54.

Anon. 1994. Tuna Turnaround. New Scientist, 1928, 11.

Camphuysen, C.J. and Leopold, M.F. 1993. The harbour porpoise Phocoena phocoena in the southern North Sea, particularly the Dutch sector. Lutra, 36 (1), 11-24.

Charreire, F. 1992. A Report for Greenpeace on Recent Dolphin Strandings along the French Atlantic Coast. Unpublished.

Clausen, B. and Andersen, S. 1988. Evaluation of bycatch and health status of the harbour porpoise (Phocoena phocoena) in Danish waters. Danish Review of Game Biology, 13 (5), 2-20.

Cockcroft, V.G., DeKock, A.C., Lord, D.A. and Ross, G.J.B. 1989. Organochlorines in bottlenose dolphins (Tursiops truncatus) from the east coast of South Africa. S. Afr. J. Mar. Sci. 8, 207-217.

Cummins, J.E. 1988. Extinction - the PCB threat to marine mammals. The Ecologist, 18 (6), 193-195.

De Swart, R.L., Ross, P.S., Vedder, L.J., Timmerman, H.H., de Heisterkamp, S.H., Van Loveren, H., Voss, J.G., Reijnders, P.J.H. and Osterhaus, A.D.M.E. 1994. Impairment of immune function in harbor seals (Phoca vitulina) feeding on fish from polluted waters. Ambio, 23 (2), 155-159.

Eis, D. 1989. Simplification in the etiology of recent seal deaths. Ambio, 18, 144.

Evans, P.G.H. 1987. The Natural History of Whales and Dolphins. Christopher Helm (Publishers) Ltd, Bromley.

Evans, P.G.H. 1990a. Cetaceans. In 1990 North Sea Report., pp. 89-101. The Marine Forum, London.

Evans, P.G.H. 1990b. European cetaceans and seabirds in an oceanographic context. Lutra, 33, 95-125.

Goujon, M., Antoine, L., Collet, A. and Fifas, S. 1993. Approche de l'Impact Ecologique de la Pêcherie Thonière au Filet Maillant Dérivant en Atlantique Nord-est. Rapport interne de la Direction des Resources Vivantes de 1'IFREMER.

Hall, A.J., Law, R.J., Wells, D.E., Harwood, J., Ross, H.M., Kennedy, S., Allchin, C.R., Campbell, L.A. and Pomeroy, P.P. 1992. Organochlorine levels in common seals (Phoca vitulina) which were victims and survivors of the 1988 phocine distemper epizootic. The Science of the Total Environment, 115, 145-162.

Hutchinson, J.D. and Simmonds, M.P. 1994. Organochlorine contamination in pinnipeds. Reviews of Environmental Contamination and Toxicology, 136, 123-167.
IWC. 1990. Executive Summary of The Workshop on the Mortality of Cetaceans in Passive Fishing Nets and Traps, La Jolla, California, 22-25 October 1990.

Julshamn, K., Andersen A., Ringdal, $O$. and Morkore, J. 1987. Trace elements intake in the Faroe Islands. I. Element levels in edible parts of pilot whales (Globicephalus melaena). The Science of the Total Environment, 65, 53-62.

Kannan, K., Tanabe, S., Borrell, A., Aguilar, A., Focardi, S. and Tatsukawa, 1993. Isomer-specific analysis and toxic evaluation of polychlorinated biphenyls in striped dolphins affected by an epizootic in the western Mediterranean sea. Arch. Environ. Contam. Toxicol. 25, 227-233.

Kelleher, G. and Kenchington, R. 1992. Guidelines for Establishing Marine Protected Areas. A Marine Conservation and Development Report. IUCN, Gland, Switzerland. vii +79 pp.

Klinowska, M. 1991. Dolphins, Porpoises and Whales of the World. The IUCN Red Data Book. IUCN, Ireland, Switzerland and Cambridge, UK.

Kuiken, T., Hofle, U., Bennett, P.M., Allchin, C.R., Kirkwood, J.K., Baker, J.R., Appleby, E.C., Lockyer, C.H., Wotton, M.J. and Sheldrick, M.C. 1993. Adrenocortical hyperplasia, disease and chlorinated hydrocarbons in the harbour porpoise (Phocoena phocoena). Marine Pollution Bulletin, 26 (8), 440-446.

Kuiken, T., Simpson, V.R., Allchin, C.R., Bennet, P.M., Lodd, G.A., Harris, E.A, Howes, G.J., Kennedy, S., Kirkwood, J.K., Law, R.J., Merrett, N.R. and Phillips, S. 1994. Mass mortality of common dolphins (Delphinus delphis) due to incidental capture in fishing gear. The Veterinary Record, January 22, 1994, 81-89.

Law, R.J. and Whinnett, J.A. 1992. Polycyclic aromatic hydrocarbons in muscle tissue of harbour porpoises (Phocoena phocoena) from UK Waters. Marine Pollution Bulletin, 24 (11), 550-553.

Law, R.J., Jones, B.R., Baker, J.R., Kennedy, S., Milne, R. and Morris, R.J. 1992. Trace metals in the livers of marine mammals from the Welsh coast and the Irish Sea. Marine Pollution Bulletin, 24, 296-304.

Lockyer, C. 1990. Review of incidents involving wild sociable dolphins, worldwide. In The Bottlenose Dolphin (eds S. Leatherwood and R. R. Reeve). Academic Press Inc., San Diego and London.

Lockyer, C. and Müller-Helmbrecht, A. 1993. ASCOBANS - Conservation Progress. The Pilot, July 1993, 14-16.

Ljungblad, D.K., Wursig, B., Swartz, S.L. and Keene, J.M. 1985. Observations on the behaviour of bowhead whales (Balaena mysticetus) in the presence of operating seismic exploration vessels in the 
Alaskan Beaufort Sea. OCS study MMS 85-0076. Rep. from SEACO Inc., San Diego, California, for USMMS. NTIS PB87-129318.

Lyster, S. 1985. International Wildlife Law. Grotius Publications Ltd, Llandysul.

Martin, A.R. 1990. Whales and Dolphins. Salamander Books Ltd, London.

May, J. (Editor) 1990. The Greenpeace Book of Dolphins. Random Century (Pty) Ltd, London.

Morris, R.J., Law, R.J., Allchin, D.R., Kelly, C.A. and Fileman, C.F. 1989. Metals and organochlorines in dolphins and porpoises of Cardigan Bay, West Wales. Marine Pollution Bulletin, 20, 512-523.

Peterle, T.J. 1991. Wildlife Toxicology. Van Nostrand Reinhold, New York.

Rawson, A.J., Patten, G.W., Hofmann, S., Pietra, G.G. and Johns, L. 1993. Liver abnormalities associated with chronic mercury accumulation in stranded Atlantic bottlenose dolphins. Ecotoxicology and Environmental Safety, 25, 41-47.

Reeves, R.R. 1992. Whale Responses to Anthropogenic Sounds: A Review. Prepared for the Department of Conservation, Wellington, New Zealand.

Reijnders, P.J.H. 1986. Reproductive failure in common seals feeding on fish from polluted coastal waters. Nature, 324, 456-457.

Reijnders, P.J.H. 1992. Harbour porpoises, Phocoena phocoena, in the North Sea: numerical responses to changes in environmental conditions. Netherlands Journal of Aquatic Ecology, 26 (1), 75-85.

Richardson, W.J., Davis, R.A., Evans, C.R. and Norton, P. 1985. Distribution of bowheads and industrial activity 1908-84. In Behaviour, Disturbance Responses and Distribution of Bowhead Whales Balaena mysticetus in the eastern Beaufort Sea, 1980-84 (ed. W. J. Richardson). OCS Study MMS 85-0034. Rep. from LGL Ecol. Res. Assoc. Inc., Bryan TX for US Minerals Management Service, Reston VA, NTIS PB-124376, 255-301.

Richardson, W.J., Wursig, B. and Greene, C.R. Jr. 1986. Reactions of bowhead whales (Balaena mysticetus) to seismic exploration in the Canadian Beaufort Sea. J. Acoust. Soc. Am. 79 (4), 1117-1128.

Richardson, W.J., Davis, R.A., Evans, C.R., Ljungblad, D.K. and Norton, P. 1987. Summer distribution of bowhead whales, Balaena mysticetus, relative to oil industry activities in the Canadian Beaufort Sea, 1980-1984. Arctic, 40 (2), 93-104.

Rose, G. and Crane, S. 1993. The evolution of International Whaling Law. In Greening International Law (ed. P. Sands). Earthscan Publications Ltd, London.

Safe, S. 1984. Polychlorinated biphenyls (PCBs) and polybrominated biphenyls (PBBs): biochemistry, toxicology and mechanism of action. CRC Critical Review of Toxicology, 13, 319-395.
Simmonds, M.P. 1992. Cetacean Mass Mortalities and their potential relationship with pollution. Symposium - Whales: Biology, Threats and Conservation, Brussels, 5-7 June 1991. Royal Academy of Sciences, 217-245.

Simmonds, M.P. and Hutchinson, J.D. 1994. Recent mortality events and their implications for the conservation of dolphin species. Scientific Symposium on the 1993 North Sea Quality Status Report, 18-21 April 1994. Ebeltoft, Denmark.

Simmonds, M.P., Johnston, P.A. and French, M.C. 1993. Organochlorine and mercury contamination in United Kingdom seals. The Veterinary Record, 20 March 20, 291-295.

Simmonds, M.P., Johnston, P.A., French, M.C., Reeve, R. and Hutchinson, J.D. 1994. Organochlorines and mercury in pilot whale blubber consumed by Faroe Islanders. The Science of the Total Environment, 149 (1-2), 97-111.

Subramanian, A.N., Tanabe, S., Tatsukawa, R., Saito, S. and Miyazaki, N. 1987. Reduction in the testosterone levels by PCBs and DDE in Dall's porpoises of Northwestern North Pacific. Marine Pollution Bulletin, 18 (12), 643-646.

Tregenza, N.J.C. 1992. Fifty years of cetacean sightings from the Cornish Coast, SW England. Biological Conservation, 59, 65-70.

Vinther, M. 1994. Incidental catch of harbour porpoise (Phocoena phocoena) in the Danish North Sea gill-net fisheries. Preliminary Results. Scientific Symposium on the 1993 North Sea Quality Status Report, 18-21 April 1994. Ebeltoft, Denmark.

Woodley, T.H. and Earle, M. 1991. Observations on the French Albacore Driftnet Fishery of the Northeast Atlantic. Report for Greenpeace International. Unpublished. $11 \mathrm{pp}$.

Woodley, T.H. and Read, A.J. 1991. Potential rates of increase of a harbour porpoise (Phocoena phocoena) population subjected to incidental mortality in commercial fisheries. Can. J. Fish. Aquat. Sci. 48, 2429-2435.

Würsig, B. 1986. Delphinid foraging strategies. In Dolphin Cognition and Behaviour: A Comparative Approach (eds. R. J. Schustermann, J. A. Thomas and F. G. Wood). LEA Publishers, New Jersey and London.

Zachariassen, P. 1993. Pilot whale catches in the Faroe Islands, 1709-1992. In Biology of Northern Hemisphere Pilot Whales (eds G. P. Donovan, C. H. Lockyer and A. R. Martin). Report of the International Whaling Commission Special Issue 14, Cambridge.

Mark P. Simmonds, Conservation Research Group, School of Environmental Sciences, The University of Greenwich, Creek Road, London SE8 3BU, UK. 